\title{
The mycobiota of needles and shoots of silver fir (Abies alba Mill.) with symptoms of Herpotrichia needle browning in the Tatra Mts. (Poland)
}

\author{
Wojciech Pusz ${ }^{1}$, Anna Baturo-Cieśniewska², Agata Kaczmarek -Pieńczewska ${ }^{1 \rrbracket}$, Tomasz \\ Zwijacz-Kozica³, Katarzyna Patejuk'
}

Pusz W., Baturo-Cieśniewska A., Kaczmarek-Pieńczewska A., ZwijaczKozica T., Patejuk K., 2020. The mycobiota of needles and shoots of silver fir (Abies alba Mill.) with symptoms of Herpotrichia needle browning in the Tatra Mts. (Poland) Ann. For. Res. 63(2): 45-56.

Abstract The European silver fir (Abies alba Mill.) has the largest distribution area of all the European species of fir. It is the only species of this type found in the Carpathian Mts., including their highest range - the Tatras, where it constitutes one of the main components of lower montane forests. In certain sections of the Carpathian Mountains fir stands are affected by the competitive pressure of beech. This may be due to climate change, as well as biotic factors such as plant diseases. One such disease is Herpotrichia needle browning. The goal of the present research was to assess the occurrence of Herpotrichia needle browning in the Tatra National Park and determine the species composition of fungi colonizing symptomatic needles and shoots. Symptoms of the disease were observed across the entire research period, i.e., from May to mid-September 2019. They included the wilting of the needles with subsequent mycelial growth on the remains, as well as shoot deformation. The mycological analysis of the needles and shoots of $A$. alba resulted in the isolation of 22 fungal taxa. In the case of the needles and shoots, which showed symptoms of infection, the most frequent species of fungus was Sydowia polyspora (Bref. \& Tavel) E. Müll., followed by Alternaria alternata (Fr.) Keissl. and Rhizosphaera macrospora Gourb. \& M. Morelet. Herpotrichia needle browning seems to be triggered by a complex disease resulting from synergistic interaction of several fungal pathogens.

Keywords: Tatra National Park; health status of silver fir; Herpotrichia needle browning; Herpotrichia parasitica; Nematostoma parasiticum

Addresses: ${ }^{1}$ Department of Plant Protection, Division of Plant Pathology and Mycology, Wrocław University of Environmental and Life Sciences, Wrocław, Poland $\mid{ }^{2}$ Department of Biology and Plant Protection, Laboratory of Phytopathology and Molecular Mycology, UTP University of Science and Technology, Bydgoszcz, Poland ${ }^{3}$ Tatra National Park, Zakopane, Poland.

『Corresponding Author: Agata Kaczmarek-Pieńczewska (agata.kaczmarek@ upwr.edu.pl).

Manuscript received September 25, 2020; revised December 21, 2020; accepted December 23, 2020. 


\section{Introduction}

The range of the European silver fir (Abies alba Mill.) is the most extensive of all the European fir species and stretches throughout the central and southern parts of the continent. Fir stands are found in mountainous regions at low to medium altitudes. The highest altitude at which they have been observed is 2100 $\mathrm{m}$ above sea level, in the Apennines. The European silver fir can also be found growing in lowlands, but only in the northern part of its range (Boratyński 1983). It is the only species of the genus Abies found in the Carpathian Mountains. In the Tatras, it is one of the main components of lower montane forests, especially in places where the soil is rich in calcium carbonate (Radwańska-Paryska 1975). The highest fir stands in the Tatras can be found in the subalpine zone, at altitudes reaching $1590 \mathrm{~m}$ above sea level (ZwijaczKozica 2003).

Studies conducted in this part of Poland have often shown that in lower montane forests, the regeneration capacity of fir trees is much more limited than that of, for instance, beech trees; in the future, this may result in the emergence of mixed fir-beech forests (Jaworski \& Pach 2013). This may be due to climate change, but also indirectly (or directly) to biotic factors, which inhibit natural fir regeneration (Jankowiak et al. 2016).

Caused by Nematostoma parasiticum (R. Hartig) M.E. Barr (previous name: Herpotrichia parasitica (R. Hartig) Rostr.), Herpotrichia needle browning has been known in southern Poland for many years (Kowalski \& Andruch 2010, 2012). Herpotrichia needle browning of silver fir is characterized by browning and dying of both the young and old needles, which remain on the branches.

They hang loosely from the shoots, to which they remain attached by a superficial mycelium. Field observations conducted in southern Poland (Kowalski \& Andruch 2010) showed differences in the occurrence of the disease between artificially and naturally regenerated areas. Mycological analysis revealed that the dominant fungi in the mycobiota of infected needles belonged to the genus Rhizoctonia; according to the authors, the role of these fungi in the pathogenesis of Herpotrichia needle browning is difficult to determine (Kowalski \& Andruch 2010). Studies conducted in the following years confirmed earlier findings, but the role of Rhizoctonia fungi in the disease process has not yet been identified, let alone the factor facilitating its development (Kowalski \& Andruch 2012). At this time, in Poland we have not got any protection methods to control this disease.

The goal of the research conducted in the Tatra National Park was to determine the extent to which Herpotrichia needle browning threatens fir healthiness in the region, as well identify the mycobiota associated with the species responsible for the disease.

\section{Materials and methods}

\section{Fieldwork and symptoms assessment}

The study took place from April to October 2019 in the Tatra National Park (Poland) where net of 617 circular sampling plots (0.05 ha each) was established in 2016-2017 (Bodziarczyk et al. 2019).

The analysis of the occurrence of Herpotrichia needle browning was carried out in July 2019 (at this time the researchers noticed the highest numbers of needles showing symptoms), in 32 study plots containing more than 30 individuals of young A. alba (Figure 1, Table 1), located in an altitudinal range of 916-1249 (mean 1005) $\mathrm{m}$ above sea level, in multi-age forest stands dominated by Norway spruce (Picea abies) of various protective regimes (passive protection without any human interference, active protection with low level of interference and managed forest). Volume of living trees on these plots was $8-640$ (mean 326$) \mathrm{m}^{3} / \mathrm{ha}$, with basal area in the range of 1.7-60.1 (mean 29.6) 
$\mathrm{m}^{2} /$ ha, while volume of dead wood was in the range of 0-815 (mean 292) $\mathrm{m}^{3} / \mathrm{ha}$.

In order to assess the severity of the disease, the researchers employed a methodology developed by Kowalski \& Andruch (2010) whereby they described the occurrence of disease symptoms $(<25 \% ; 26-50 \%$ : 51$75 \%$; $>76 \%$ ) (Figure 2) and their position within the crowns (bottom, middle or top crown) (Table 1).

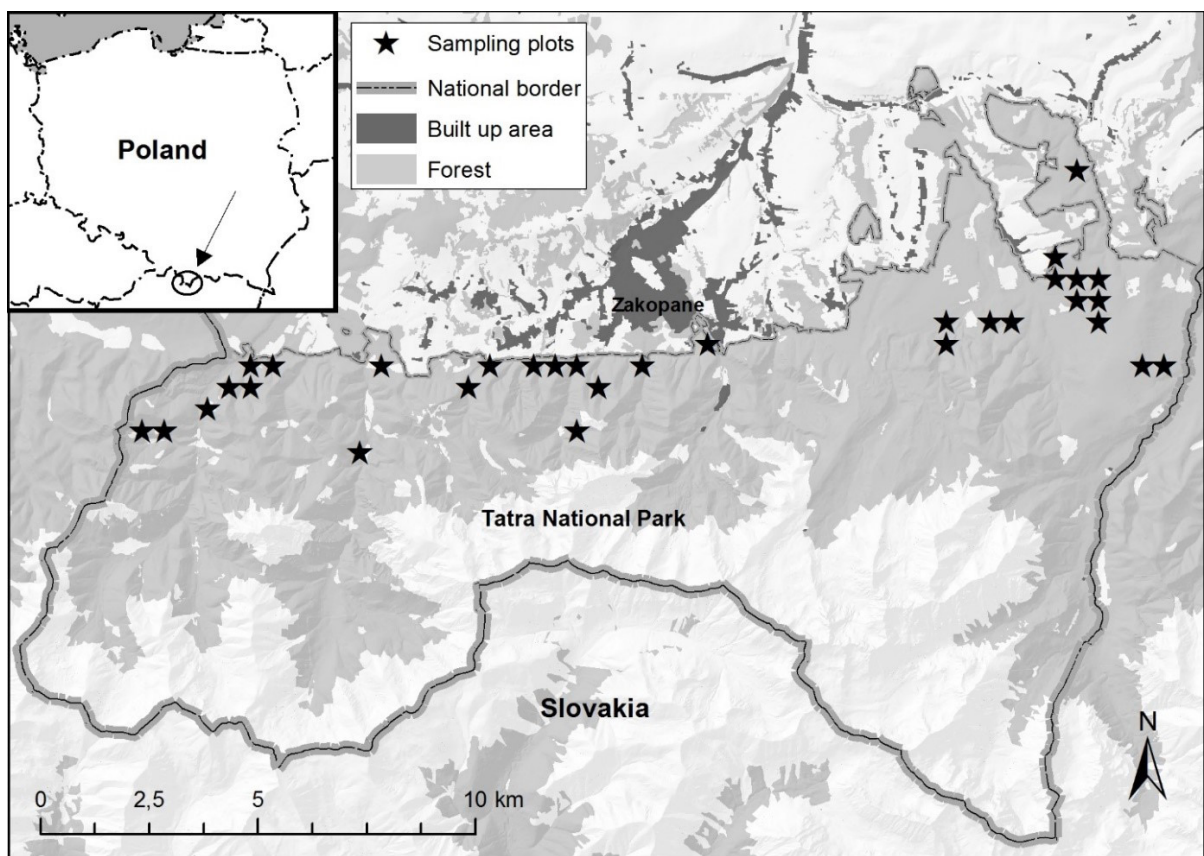

Figure 1 Map with sampling plots in Tatra National Park

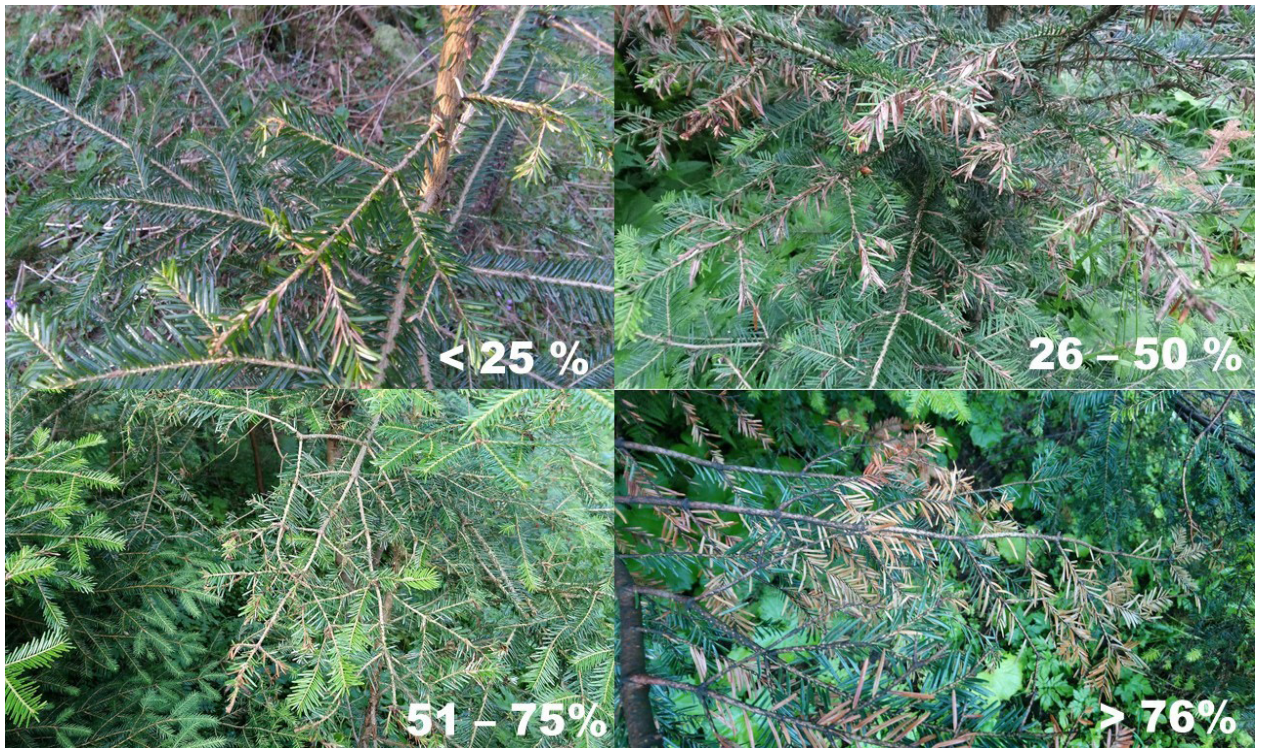

Figure 2 Symptoms of Herpotrichia needle browning according to the infection scale 
Table 1 Assessment of the occurrence of HNB symptoms in 8 sites from Tatra National Park

\begin{tabular}{|c|c|c|c|c|c|c|c|c|}
\hline \multirow[t]{2}{*}{ Site } & \multirow[t]{2}{*}{ Name of regions } & \multirow{2}{*}{$\begin{array}{l}\text { Average } \\
\text { height of } \\
\text { trees [m] }\end{array}$} & \multicolumn{3}{|c|}{$\begin{array}{c}\text { Severity of the disease } \% / \% \text { of affected } \\
\text { individuals }\end{array}$} & \multicolumn{3}{|c|}{$\begin{array}{l}\text { Position of the symptoms } \\
\text { within the crown }\end{array}$} \\
\hline & & & $<25 \%$ & $26-50 \%$ & $51-75 \%>75 \%$ & Bottom & Middle & Top \\
\hline$\overline{551}$ & Dolina & 1.3 & & 23 & 77 & $\mathrm{x}$ & $\mathrm{x}$ & $\mathrm{x}$ \\
\hline 552 & Chochołowska & 4.3 & 45 & 3 & 42 & $\mathrm{x}$ & $\mathrm{x}$ & $\mathrm{x}$ \\
\hline 601 & & 5.1 & 23 & 48 & 39 & $\mathrm{x}$ & $\mathrm{x}$ & \\
\hline 649 & & 7.5 & & 73 & 27 & $\mathrm{x}$ & $\mathrm{x}$ & $\mathrm{x}$ \\
\hline 650 & & 1.8 & 44 & 54 & 2 & $\mathrm{x}$ & $\mathrm{x}$ & \\
\hline 696 & & 4.5 & 12 & 56 & 32 & $\mathrm{x}$ & $\mathrm{x}$ & $\mathrm{x}$ \\
\hline 697 & & 7.2 & 6 & 94 & & $\mathrm{x}$ & $\mathrm{x}$ & $\mathrm{x}$ \\
\hline 702 & Droga 58 & 2.3 & 100 & & & $\mathrm{x}$ & $\mathrm{x}$ & \\
\hline 660 & Mała Łąka i Dolina & 4.3 & 95 & 5 & & $\mathrm{x}$ & $\mathrm{x}$ & \\
\hline 706 & Strążyska & 6.5 & 100 & & & $\mathrm{x}$ & $\mathrm{x}$ & \\
\hline 708 & & 4.8 & 100 & & & $\mathrm{x}$ & $\mathrm{x}$ & \\
\hline 709 & & 5.4 & 45 & 50 & 5 & $\mathrm{x}$ & $\mathrm{x}$ & \\
\hline 710 & & 0.9 & 100 & & & $\mathrm{x}$ & & \\
\hline 666 & & 1.4 & 100 & & & $\mathrm{x}$ & & \\
\hline 571 & & 1.5 & 100 & & & $\mathrm{x}$ & & \\
\hline 713 & & 1.8 & 99 & 1 & & $\mathrm{x}$ & & \\
\hline 740 & Stadion & 2.1 & 98 & & & $\mathrm{x}$ & $\mathrm{x}$ & \\
\hline 770 & Zgorzelisko & 4.3 & 87 & 13 & & $\mathrm{x}$ & $\mathrm{x}$ & \\
\hline 774 & & 6.7 & 96 & 4 & & $\mathrm{x}$ & $\mathrm{x}$ & \\
\hline 789 & & 4.5 & 98 & 2 & & $\mathrm{x}$ & $\mathrm{x}$ & \\
\hline 790 & & 2.1 & & 12 & 88 & $\mathrm{x}$ & $\mathrm{x}$ & $\mathrm{x}$ \\
\hline 804 & & 1.7 & 54 & 10 & 36 & $\mathrm{x}$ & $\mathrm{x}$ & \\
\hline 803 & & 1.5 & 98 & 2 & & $\mathrm{x}$ & $\mathrm{x}$ & \\
\hline 838 & & 1.9 & 89 & 11 & & $\mathrm{x}$ & $\mathrm{x}$ & \\
\hline 814 & & 1.8 & 99 & 1 & & $\mathrm{x}$ & & \\
\hline 805 & & 1.7 & 65 & 35 & & $\mathrm{x}$ & & \\
\hline 736 & Łysa Polana & 4.3 & 84 & 16 & & $\mathrm{x}$ & $\mathrm{x}$ & \\
\hline 737 & & 3.5 & 95 & 3 & & $\mathrm{x}$ & & \\
\hline 767 & Wawrzeczkowa & 1.7 & 100 & & & $\mathrm{x}$ & & \\
\hline 751 & Cyrhla & 1.9 & 100 & & & $\mathrm{x}$ & & \\
\hline 769 & & 1.6 & 100 & & & $\mathrm{x}$ & & \\
\hline 514 & Dolina Kościeliska & 2.1 & 100 & & & $\mathrm{x}$ & & \\
\hline
\end{tabular}

\section{Laboratory and statistical analysis}

Only the needles in which discoloration covered $50-60 \%$ of the surface area were sampled for mycological analysis. The needles were disinfected for one minute in $0.5 \%$ sodium hypochlorite and rinsed in sterile water. They were cut then into one- to twomillimetre-long fragments, which were placed on a standard PDA medium (Potato Dextrose Agar, Biocorp, Poland). The growing fungal colonies were subsequently transferred to slants with PDA medium and cultured in order to enable their taxonomic identification. The fungi were identified under a light microscope on the basis of their morphological traits such as the dimension of spores, colour, shape, etc. (Minter 1981, Pitt \& Hocking 2009, Watanabe 2011). Independently of morphological identification, the taxa were also identified using molecular methods by analyzing the ITS (Internal Transcribed Spacer) regions of the rDNA. 
For the purposes of molecular analysis, pure cultures of representative 40 isolates were grown in darkness at $23^{\circ} \mathrm{C}$ on Petri dishes with PDA (Potato Dextrose Agar, Difco); they were grown over a period of one to two weeks, depending on the species. Subsequently, three discs $5 \mathrm{~mm}$ in diameter were excised from the growing colonies on each Petri dish, transferred to Petri dishes containing PDB (Potato Dextrose Broth, A\&A Biotechnology), sealed with Parafilm $M$ and incubated in darkness for a period of 7-10 days. The mycelium obtained in liquid culture was rinsed with sterile water and drained using a lab filter set composed of filter paper, Büchner funnel and vacuum pump. The material was then placed in CoolSafe lyophiliser (Scanvac) for 48 hours. DNA was extracted from $30 \mathrm{~g}$ of mycelium, homogenized prior to extraction in MagnaLyser homogeniser (Roche) using quartz beads, following modified Doyle and Doyle (1990) method. Nine hundred microliters of extraction buffer contained CTAB 5.0\%, EDTA $0.5 \mathrm{M}, \mathrm{NaCl} 5.0 \mathrm{M}$, Tris- $\mathrm{HCl}$ (pH 8.0) 1.0 M, $\beta$-mercaptoethanol; PVP 2.0\% was used. Phenol, chloroform, isoamyl alcohol and ethyl alcohol were used to purify and then precipitate the DNA in the following steps. DNA suspended in $100 \mu \mathrm{l}$ of ddH2O was purified with Anti-inhibitor Kit (A\&A Biotechnology). DNA concentration was measured using Quantus Fluorometer (Promega).

The ITS regions were amplified in 37.5 $\mu \mathrm{l}$ containing reagents from the PCR Core Kit (QIAGEN, USA): 1x buffer, 1x Q solution, $1 \mathrm{mM} \mathrm{MgCl} 2,0.2 \mathrm{mM}$ dNTP, $0.6 \mathrm{pM}$ of each of the two primers (ITS1: 5'-TCCGTAGGTGAACCTGCGG-3' and ITS4: 5'-TCCTCCGCTTATTGATATGC-3' (White et al. 1990), and DNA was brought to a final concentration of $5 \mathrm{ng} \cdot \mu \mathrm{l}-1$. The DNA was amplified using Eppendorf Mastercycler, according to the following reaction protocol: initial denaturation at $94{ }^{\circ} \mathrm{C}$ for $5 \mathrm{~min}$ followed by 35 cycles $\left(1 \mathrm{~min}\right.$ at $94{ }^{\circ} \mathrm{C}, 1 \mathrm{~min}$ at $52{ }^{\circ} \mathrm{C}$,
2 min at $72{ }^{\circ} \mathrm{C}$ ) and final elongation at $72{ }^{\circ} \mathrm{C}$ for $5 \mathrm{~min}$. The presence of reaction products was verified by electrophoretic separation in TBE buffer performed on $1.4 \%$ agarose gel (Pronadisa), with the addition of SimplySafe dye (EURX). The amplification products were purified and sequenced by Genomed (Poland). FinchTV 1.4. software was used to analyse the obtained sequences.

For taxonomic identification we applied percent identity, E-value and query coverage of the Basic Local Alignment Search Tool (BLASTn) in the NCBI (The National Centre for Biotechnology Information) database (accessed on 23 March 2020). In a very few cases percent identity values were slightly < $100 \%$. For this reason, we confirmed species identification of these single isolates based on morphological features, as well as for Alternaria alternata isolates with percent identity $=100 \%$, due to the fact that Alternaria genus is considered to be difficult to identify on the basis of the ITS regions. In case of doubt, when molecular methods failed to identify at species level, the identification was limited to the level of genus. Trichoderma spp. identification was additionally confirmed by analyzing the sequences of ITS regions in TrichOKey v. 2.0 (Druzhinina et al. 2005). The nomenclature of the identified taxa is in accordance with the Catalogue of Life (accessed on 23 March 2020) and the Index Fungorum (accessed on 23 March 2020).

Based on achieved results the differences in the average infection severity between regions of conducted studies were present on box-plot graph. Following Kowalski \& Andruch (2010) a preferable position in the tree-crown of fir needle's browning symptoms occurrence and share of species in total mycobiota occurring four types of fir tissues were present on bar charts. Moreover, the linear regression between average tree height and the grade of infection by Herpotrichia needle browning was calculated. Graphical representations and basic statistics were made in Tableau (2020.2.4 Professional Edition). 


\section{Results}

Symptoms of the disease were observed throughout the entire research period, i.e., from May to the beginning of October, peaking during the summer months in 2019 . They included the wilting of the needles with subsequent mycelial growth on the remains, as well as shoot deformation. Areas with the lowest incidence of symptoms included the Kościeliska Valley, Wawrzeczkowa Cyrhla, the site by national road no. 58 , as well as the Małej Łąki Valleys and Strążyska Valley (Table 1). At these locations, the central and lower parts of the crowns showed symptoms of the disease, but the symptomatic areas constituted no more than $25 \%$ of the total surface area of each tree crown. An exception to this were the specimens in site no. 709, half of which had symptoms of the disease extending to $50 \%$ of their surface area. In regenerated forests in Zgorzelisko and Łysa Polana, as well as in the vicinity of the stadium in Zakopane, between $54 \%$ and $99 \%$ specimens showed symptoms of infection on less than $25 \%$ of their surface area. In sites no. 790 and 804, more than 50\% of trees were symptomatic: $88 \%$ and $36 \%$ levels of incidence, respectively.

Incidence of the disease seemed highest at sites located in the Chochołowska Valley (Figure 3); the majority of trees in all areas under study showed symptoms of infection on $26-51 \%$ of crowns, and in site no. 551 the symptoms extended to more than $50 \%$ of shoot surface area. In this particular site, symptoms of the disease were also observed in the upper parts of the trees. Symptoms of the disease were observed all over the trees, depending on the site. Moreover, at the bottom of the crown they were present on every studied specimen (Figure 4). Intensity of the needle infection decreased with position within the crown, on the middle part symptoms were present on $65.6 \%$ of trees, and on the top only on $18.8 \%$. Also, average height of the tree got a weak impact to the intensity of needle infection, linear regression shown.

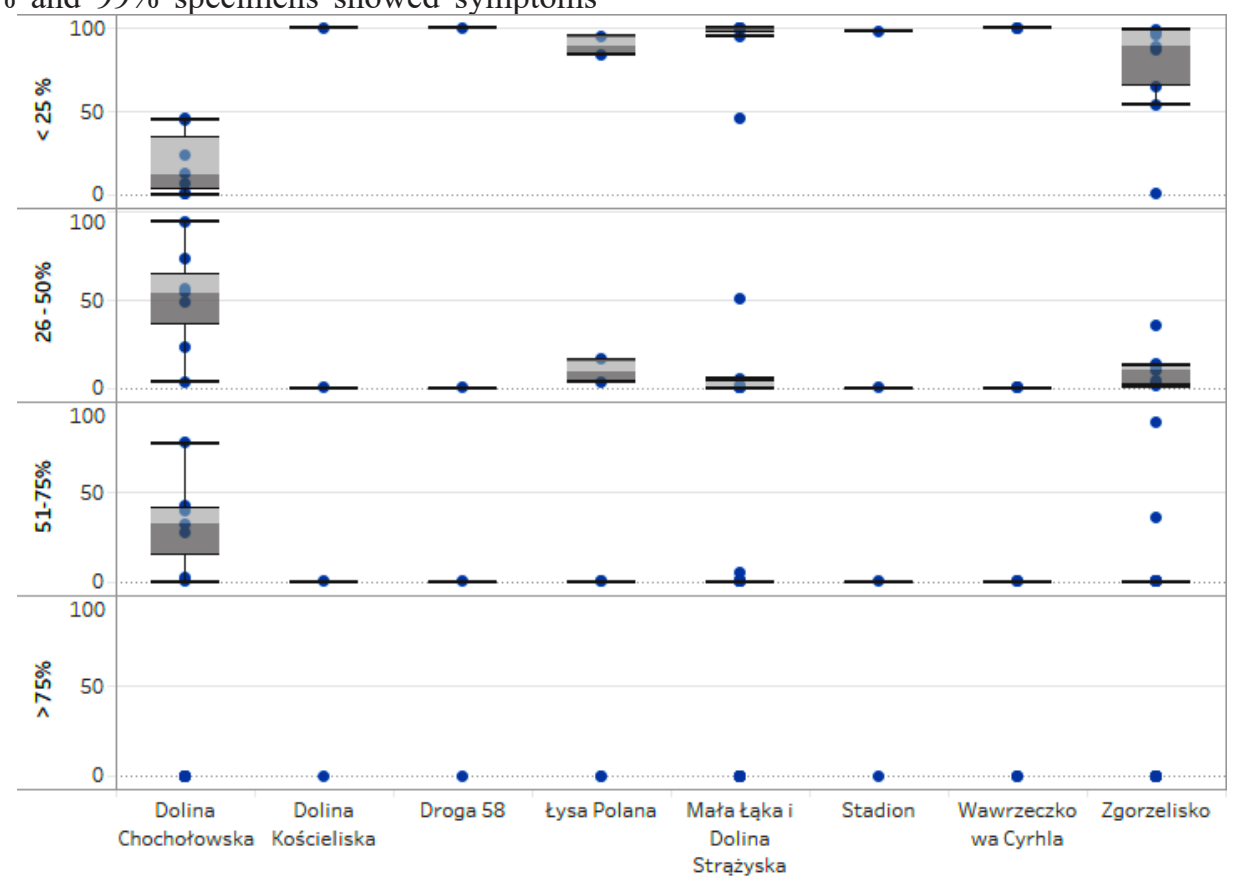

Figure 3 Box-plot representation of the average infection severity of the fir needles according to four-level health status scale ( 8 sites in Tatra National Park) 


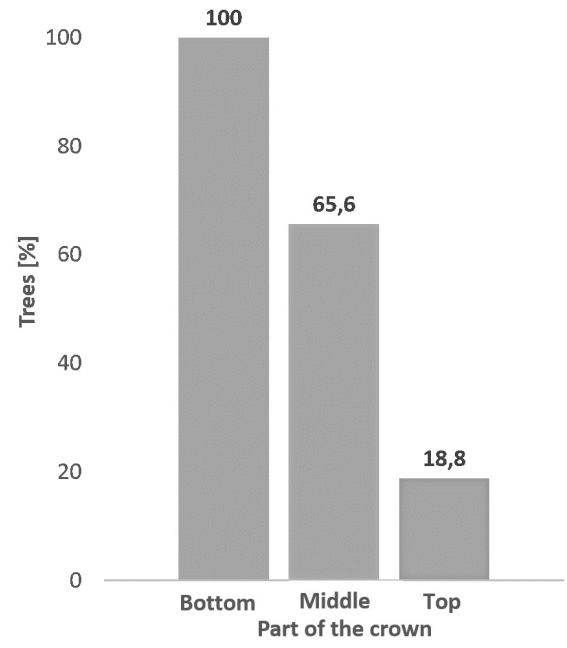

Figure 4 Fir needles' disease incidence at different positions within the tree-crown

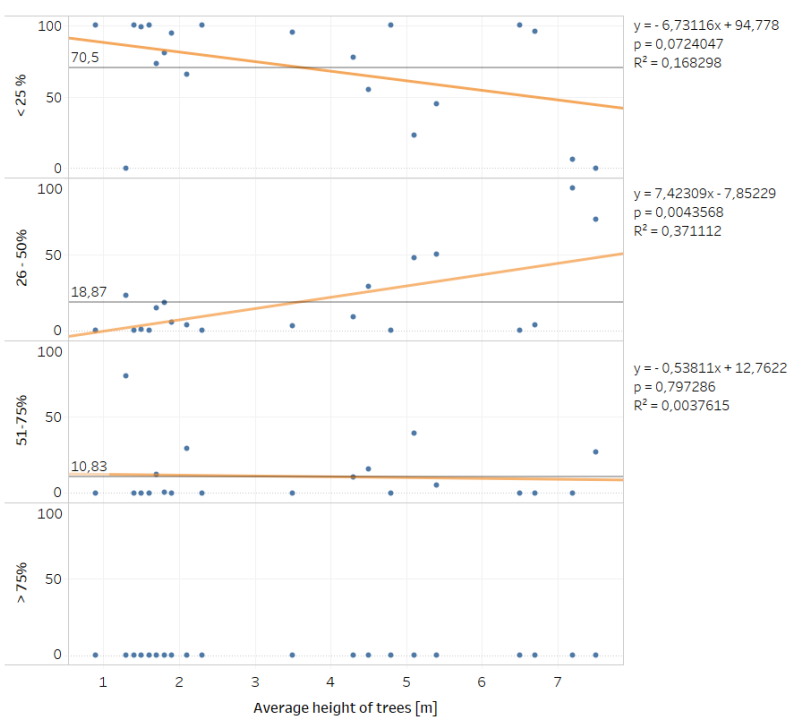

Figure 5 Linear regression of Herpotrichia needle browning symptoms according to the 4-grade infection scale, against the average height of infected trees. Grey line - average of infected plants, orange - trend line

According to the Figure 5, smaller trees were less affected by severe symptoms of disease, that mostly occurred less than on $25 \%$ surface of the tree. Significant difference in lineal regression was observed in case of symptoms on second level on the scale (26-50\%), which affected preferentially taller trees, although observed correlation was not strong $(\mathrm{p}<0.0043$, $\left.\mathrm{R}^{2}=0.371112\right)$. However, in average $70.5 \%$ of the trees showed few symptoms $(<25 \%)$ of the ongoing disease. Severe symptoms were rare, in average only $18.87 \%$ of trees were affected, corresponding to the second level of the health scale, and $10.83 \%$ having more than $51-75 \%$ of the crown surface attacked. Symptoms occurring $51-75 \%$ of crown were observed on singular trees, with no significant differences to the tree's height $\left(\mathrm{p}>0.0797, \mathrm{R}^{2}>0.003\right)$. There was no site, where symptoms of disease would occupy more than $75 \%$ surface of the tree crowns.

A mycological analysis of the needles and shoots of $A$. alba resulted in the isolation of 22 fungal taxa (Table 2). In the case of the needles that showed symptoms of infection, the dominant species was Sydowia polyspora (Bref. \& Tavel) E. Müll. (34\%), followed by Alternaria alternata (Fr.) Keissl. (26\%) and Rhizosphaera macrospora Gourb. \& M. Morelet (16.7\%) (Figure 6). A similar pattern was observed when isolating fungi from symptomless needles. In their case, the dominant species were S. polyspora $(45 \%)$ and A. alternata (36\%), while $R$. macrospora was not observed at all. The dominant taxa in the mycobiota of symptomatic shoots included an unidentified species belonging to the genus Phomopsis (55\%), and $R$. macrospora (nearly 20\%). In the case of the shoots that were symptomless, the dominant 
fungi included Nigrospora oryzae (Berk. \& of the fungus $N$. parasiticum, which is Broome) Petch (28\%) and A. alternata (26\%). responsible for Herpotrichia needle browning, An analysis of infested needles was performed were observed on dying needles; in several additionally in order to ascertain the presence of in vivo fungal structures. In May, pycnidia cases, the presence of Curvularia spores was also detected.

Table 2 The frequency of fungi isolated from the symptomatic and asymptomatic needles and shoots of Abies alba in Tatra Mts., identification based on ITS regions [\%]

\begin{tabular}{|c|c|c|c|c|c|}
\hline Fungal taxa & $\begin{array}{l}\text { Accesion number in } \\
\text { NCBI }\end{array}$ & $\begin{array}{r}\text { Needles } \\
\text { with } \\
\text { disease } \\
\text { symptoms }\end{array}$ & $\begin{array}{r}\text { Needles } \\
\text { without } \\
\text { disease } \\
\text { symptoms }\end{array}$ & $\begin{array}{r}\text { Shoots } \\
\text { with } \\
\text { disease } \\
\text { symptoms }\end{array}$ & $\begin{array}{r}\text { Shoots } \\
\text { without } \\
\text { disease } \\
\text { symptoms }\end{array}$ \\
\hline $\begin{array}{l}\text { Alternaria alternata }(\mathrm{Fr} .) \\
\text { Keissl. }\end{array}$ & $\begin{array}{l}\text { MN539533, MN539537, } \\
\text { MN539535, MN538263, } \\
\text { MN538264, MN539538 }\end{array}$ & 26 & 36 & 2.8 & 26.3 \\
\hline $\begin{array}{l}\text { Arthrinium arundinis (Corda) } \\
\text { Dyko \& B. Sutton }\end{array}$ & MN538265, MN538266 & & 3 & 1.4 & \\
\hline $\begin{array}{l}\text { Biscogniauxia mediterranea } \\
\text { (De Not.) Kuntze }\end{array}$ & MN538267 & & & 2.8 & \\
\hline Chaetomium globosum Kunze & MN538273 & & & 2.1 & \\
\hline Coniochaeta sp. & MN538293 & & & 2.1 & \\
\hline Entoleuca sp. & MN538292 & & 1 & & 14 \\
\hline Epicoccum nigrum Link & MN539539 & 9 & 1 & & 1.7 \\
\hline $\begin{array}{l}\text { Hypoxylon fragiforme (Pers.) J. } \\
\text { Kickx f. }\end{array}$ & MN538296 & & & 5 & \\
\hline $\begin{array}{l}\text { Nigrospora oryzae (Berk. \& } \\
\text { Broome) Petch }\end{array}$ & $\begin{array}{l}\text { MN538302, MN538309, } \\
\text { MN538303 }\end{array}$ & 5 & 1 & & 28.1 \\
\hline Periconia byssoides Pers. & MN538310 & & & 0.7 & \\
\hline Phomopsis sp. & $\begin{array}{l}\text { MN538322, MN538333, } \\
\text { MN538332, MN538334, } \\
\text { MN538335 }\end{array}$ & & 3 & 55.5 & 21.1 \\
\hline $\begin{array}{l}\text { Rhizosphaera macrospora } \\
\text { Gourb. \& M. Morelet }\end{array}$ & MN538336, MN538337 & 16.7 & & 19.8 & \\
\hline $\begin{array}{l}\text { Rosellinia corticium (Schwein.) } \\
\text { Sacc. }\end{array}$ & $\begin{array}{l}\text { MN538338, MN539534, } \\
\text { MN538339 }\end{array}$ & & & 2.1 & 5.3 \\
\hline $\begin{array}{l}\text { Sirococcus conigenus (Pers.) P.F. } \\
\text { Cannon \& Minter }\end{array}$ & MN538340 & & & 0.7 & \\
\hline $\begin{array}{l}\text { Sordaria fimicola (Roberge ex } \\
\text { Desm.) Ces. \& De Not. }\end{array}$ & MN538351, MN538350 & & & 2.1 & 3.5 \\
\hline $\begin{array}{l}\text { Sydowia polyspora (Bref. \& } \\
\text { Tavel) E. Müll. }\end{array}$ & MN538353, MN538352 & 34 & 45 & & \\
\hline Tricharina sp. & MN538354 & 7 & & & \\
\hline Trichoderma harzianum Rifai & MN539536 & 2.3 & 10 & & \\
\hline Xylaria longipes Nitschke & MN538355 & & & 1.5 & \\
\hline Xylaria sp. & MN538356 & & & 1.4 & \\
\hline
\end{tabular}




\section{Discussion}

Herpotrichia needle browning has been present in southern Poland for many years (Kowalski \& Andruch 2010). It occurs also in other European countries, such as Austria, Switzerland, Denmark and Great Britain (Kowalski \& Andruch 2012). In Western Norway it causes the death of younger Abies individuals (Talgø \& Stensvand 2012). However, mycological analyses have shown significant involvement of Rhizoctonia species (Kowalski \& Andruch 2012). Some researchers claim that these fungi are the primary cause of Herpotrichia needle browning (Butin 2014). However, no Rhizoctonia species were detected during the mycological analysis of the symptomatic needles, even in the case of shoots that showed clear disease symptoms. The most common species in the mycobiota of needles showing evident symptoms of the disease was $S$. polyspora.

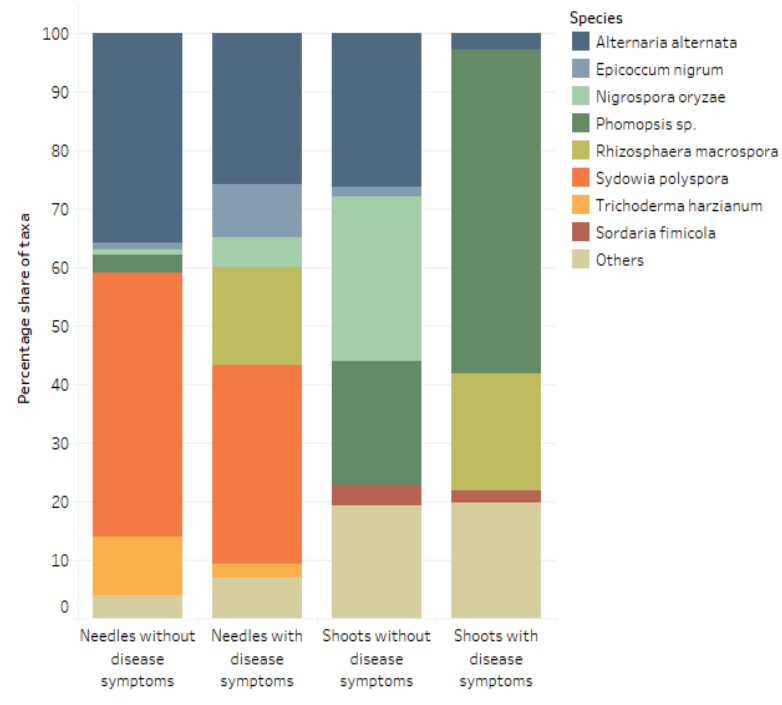

Figure 6 Percentage share of fungal taxa occurring in infected and symptomless tissues of ongoing Herpotrichia needle browning

This fungus is regarded as an accompanying species in the process of current season needle necrosis (CSNN). Previous studies suggest that this phenomenon may be due to both abiotic and biotic factors. Numerous species of fungi, both pathogenic and saprotrophic were isolated from symptomatic needles, including S. polyspora (Talgø et al. 2010). Recent findings suggest that this particular species is capable of colonizing vascular bundles of needles, and as such, it can be regarded as a secondary pathogen infecting damaged tissues, for example, as a result of insect feeding activity (Pan et al. 2018). It may also cause the death of seedlings, which in turn can have a significant impact on natural regeneration (Ridout \& Newcombe 2018). This observation has been confirmed by Jankowiak et al. (2016), who found that this species was abundant in the mycobiota of seedlings in the regenerated fir stands in southern Poland.

Another dominant species in the mycobiota of both symptomatic and asymptomatic needles was the cosmopolitan fungus $A$. alternata. This fungus colonizes tissues damaged by other disease agents and is isolated primarily from dying fir needles (Kowalski \& Andruch 2012). A high proportion of $R$. macrospora was also found in the mycobiota of needles and shoots showing symptoms of infection by Herpotrichia needle browning. These results are in agreement with those obtained by Kowalski \& Andruch (2012), who isolated this species from symptomatic tissues. A difference between the current and previous local studies about Herpotrichia disease (Kowalski \& Andruch 2012) concerns the position of the symptoms of needle's browning within the crown. In the Tatra Mountains, the bottom part of the crown, in every spot, showed symptoms of ongoing needle's disease, which were less and less visible with increasing height. Results stand in agreement with other studies (Maresi et al. 2001, Lorenzi et al. 2006) which show that Rhizosphaera sp. preferentially appears on the 
lower portion of the crown. Although, most of the studies about Rhizosphaera on coniferous trees are devoted to spruce, which are mainly affected by this genus of fungi. The increase of severe symptoms appearing on older, taller trees found, is also consistent with previous research literature (Scattolin \& Montecchio 2009, Kowalski \& Andruch 2010). In the analysed population of $A$. alba in south-eastern Poland, Kowalski \& Andruch (2010) found that the severity of the disease increases with the age of trees. Younger trees, up to $1 \mathrm{~m}$ in height, were characterized by milder symptoms. This trend was confirmed by Scattolin \& Montecchio (2009), who found extended infections caused by Rhizosphaera on older trees. However, the relation between frequent appearance of Rhizosphaera and symptoms of needle browning is not so clear. Many species in this genus, such as $R$. macrospora, are referred to as 'transient fungi'. These fungi start out as endophytes and subsequently colonize the dying tissues of their host (SieberCanavesi \& Sieber 1993), as seen in the case of fir trees, in which $R$. macrospora may be responsible for necroses (Nawrot-Chorabik \& Jankowiak 2010); some scientists regard this species as one of the most important needle pathogens (Butin 1995). However, according to the threshold value' model proposed by Sieber (2007), the significant appearance of $R$. macrospora on sympthomatic needles, can be an effect of plant stress caused by environmental changes such as drought, which trigger a switch of the fungus strategy, from endophyte to pathogen, leading to untimely needle withering. Strong correlation between $R$. macrospora with dying, browning needles and first stage of needle decomposition was found by Sieber-Canavesi \& Sieber (1993). That can suggest serious environmental disturbance in Dolina Chochołowska in last few years, where the health condition of studied firs was significantly worse than in other places in the Tatra Mountains.

Studies in Norway appear to confirm hypothesis that fir needles necrosis is caused by more than one fungal species (Talgø \& Stensvand 2012). The presence of the fungus Delphinella abietis (O. Rostr.) E. Müll., found recently in silver fir in Bulgaria (Bencheva 2017), was not detected during our research. However, it is possible that this pathogen may appear in Poland. The same is true of the fungus Pestalotiopsis funerea (Desm.) Steyaert, which is regarded as a secondary pathogen and can infect fir needles (Talgø et al. 2010). In the mycobiota of shoots with symptoms of Herpotrichia needle browning, the most frequent species included a species of Phomopsis and $R$. macrospora. This corroborates the findings of Jankowiak et al. (2016), who isolated these pathogens from A. alba seedlings in naturally regenerated fir stands. This fungus has also been isolated from damaged fir tissues (Metzler et al. 2012). Interestingly, the species Biscogniauxia mediterranea (De Not.) Kuntze, which had never been recorded in Poland before, was isolated and found to constitute almost 3\% of the mycobiota of symptomatic needles. In the Czech Republic this species is considered rare and has been observed on dead and dying wood (Zíbarová \& Kout 2017).

\section{Conclusions}

Regenerated fir stands in the Tatra National Park show symptoms of infection by fungi responsible for Herpotrichia needle browning, including $N$. parasiticum. Incidence of the disease was highest in the Chochołowska Valley and lowest in the Kościeliska Valley and Wawrzeczkowa Cyrhla. Probably it could be depending of atmospheric conditions. Mycological analysis indicated high frequency of $S$. polyspora and $R$. macrospora in the mycobiota of symptomatic needles. As such, it appears that Herpotrichia needle browning is not caused by a single fungus, but rather a combination of at least two or even three different species indicating a complex disease resulted from synergistic interactions between pathogens. 
However, further research is needed to confirm this hypothesis.

\section{Acknowledgments}

The authors would like to thank the Forest Fund for funding and financial support. The research was financed by the Forest Fund under the agreement concluded between the State Forests National Forest Holding and the Tatra National Park in 2019.

\section{References}

Bencheva S., 2017. First report of Delphinella abietis (O. Rostrup) E. müller on Abies alba Mill. in Bulgaria. Silva Balcanica 18(1): 59-62.

BLAST database, 2020. Available online: https://blast.ncbi. nlm.nih.gov/Blast.cgi?PROGRAM=blastn\&PAGE TY PE $=$ BlastSearch\&LINK LOC=blasthome (accessed on 23 March 2020).

Bodziarczyk J., Szwagrzyk J., Zwijacz-Kozica T., Zięba A., Szewczyk J., Gazda A., 2019. The structure of forest stands in the Tatra National Park: The results of 20162017 inventory. Forest Research Papers 80(1): 13-21. https://doi.org/10.2478/frp-2019-0002

Boratyński A., 1983. Systematyka i geograficzne rozmieszczenie. In Białobok S. (ed.), Jodła pospolita Abies alba Mill. PWN, Warszawa-Poznań, Poland, 41-86.

Butin H., 1995. Tree Diseases and Disorders. Causes, Biology and Control in Forest and Amenity Trees. Oxford University Press, Oxford, UK, 252 p.

Butin H., 2014. "Herpotrichia" needle browning of silver firan error and its revision. Forstschutz Aktuell 59: 12-14.

Catalogue of Life, 2020. Available online: http://www. catalogueoflife.org (accessed on 23 March 2020).

Doyle J.J., Doyle J.L., 1990. Isolation of plant DNA from fresh tissue. Focus 12: 13-15.

Druzhinina I.S., Kopchinskiy A.G., Komoń M., Bissett J., Szakacs G., Kubicek C.P., 2005. An oligonucleotide barcode for species identification in Trichoderma and Hypocrea. Fungal Genetics and Biology 42: 813-828. https://doi.org/10.1016/j.fgb.2005.06.007

Index Fungorum, 2020. Available online: http://www. indexfungorum.org/names/names.asp (accessed on 23 March 2020).

Jankowiak R., Bilański P., Paluch J., Kołodziej Z., 2016. Fungi associated with dieback of Abies alba seedlings in naturally regenerating forest ecosystems. Fungal Ecology 24: 61-69. https://doi.org/10.1016/j. funeco.2016.08.013

Jaworski A., Pach M., 2013. Zmiany udziału buka, jodły i świerka w dolnoreglowych drzewostanach naturalnych w rezerwacie „Dolina Łopusznej” (Gorczański Park Narodowy). Sylwan 157(3): 213-222. https://doi. org/10.26202/sylwan.2012079
Kowalski T., Andruch K., 2010. Herpotrichia needle browning on Abies alba in the Lesko Forest District stands: disease intensity and associated fungi. Phytopathologia 55: 21-34.

Kowalski T., Andruch K., 2012. Mycobiota in needles of Abies alba with and without symptoms of Herpotrichia needle browning. Forest Pathology 42(3), 183-190. https://doi.org/10.1111/j.1439-0329.2011.00738.x

Lorenzi E., Lorando E., Picco A.M., 2006. Microfunghi endofitici ed epifitici di Picea abies (L.) Karst. in ambiente naturale ed antropizzato in Lombardia. Forest@ 3(3): 426-436. https://doi.org/10.3832/ efor0386-0030426

Maresi G., Ambrosi P., Angeli F., Capretti P., 2001. Arrossamenti delle chiome e Rhizosphaera kalkhoffii Bubàk su Picea abies in Trentino. [Redness of the needles and Rhizosphaera kalkhoffii Bubàk on Picea abies in Trentino]. Monti e Boschi 52(3-4): 19-23.

Metzler B., Hecht U., Nill M., Brüchert F., Fink S., Kohnle U., 2012. Comparing Norway spruce and silver fir regarding impact of bark wounds. Forest Ecology and Management 274: 99-107. https://doi.org/10.1016/j. foreco.2012.02.016

Minter D.W., 1981. Lophodermium on pines. Mycological Papers 147: 1-54.

Nawrot-Chorabi K., Jankowiak R., 2010. Interakcje pomiędzy kalusem trzech genotypów Abies alba a grzybami o różnym statusie ekologicznym. [Interactions among three genotypes of Abies alba callus and fungi with different ecological status]. Leśne Prace Badawcze 71(4): 381-389. https://doi.org/10.2478/v10111-010-0033

Pan Y., Ye H., Lu J., Chen P., Zhou X.D., Qiao M., Yu Z.F., 2018. Isolation and identification of Sydowia polyspora and its pathogenicity on Pinus yunnanensis in Southwestern China. Journal of Phytopathology 166(6): 386-395. https://doi.org/10.1111/jph.12696

Pitt J.I., Hocking A.D., 2009. Fungi and food spoilage. Springer, New York, USA, 520 p. https://doi. org/10.1007/978-0-387-92207-2

Radwańska-Paryska Z., 1975. Materiały do rozmieszczenia dendroflory Tatr i Podtatrza. [Materials for the distribution of dendroflora of the Tatras and Podtatrze]. Studia Ośrodka Dokumentacji Fizjograficznej PAN 4: 13-77.

Ridout M., Newcombe G., 2018. Sydowia polyspora is both a foliar endophyte and a preemergent seed pathogen in Pinus ponderosa. Plant Disease 102(3): 640-644. https://doi.org/10.1094/PDIS-07-17-1074-RE

Scattolin L., Montecchio L., 2009. Lophodermium piceae and Rhizosphaera kalkhoffii in Norway spruce: Correlations with host age and climatic features. Phytopathologia Mediterranea 48(2): 226-239. https:// doi.org/10.14601/Phytopathol_Mediterr-2789

Siber-Canavesi F., Sieber T.N., 1993. Successional patterns of fungal communities in needles of European silver fir (Abies alba Mill.). New Phytologist 125: 149-161. https://doi.org/10.1111/j.1469-8137.1993.tb03873.x

Talgø V., Chastanger G., Thomsen I., Cech T., Riley K., 
Lange K., Klemsdal S., Stensvand A., 2010. Sydowia polyspora associated with current season needle necrosis (CSNN) on true fir (Abies spp.). Fungal Biology 114(7): 545-554. https://doi.org/10.1016/j. funbio.2010.04.005

Talgø V., Stensvand A., 2012. Foliage diseases on true fir (Abies spp.) in Norway. Journal of Agricultural Extension and Rural Development 4(9): 246-251. https://doi.org/10.5897/JAERD12.061

Watanabe T., 2010. Pictorial atlas of soil and seed fungi: morphologies of cultured fungi and key to species, 3rd ed. CRC Press, Boca Raton, USA, 426 p. https://doi. org/10.1201/EBK1439804193-c3
White T.J., Bruns T., Lee S., Taylor J., 1990. Amplification and direct sequencing of fungal ribosomal RNA genes for phylogenetics. In Innis M.A., Gelfand D.H., Sninsky J.J., White T.J. (ed.), PCR Protocols: A guide to methods and applications. Academic Press, San Diego, CA, USA, pp 315-322. https://doi.org/10.1016/b978-012-372180-8.50042-1

Zíbarová L., Kout J., 2017. Xylariaceous pyrenomycetes from Bohemia: species of Biscogniauxia and Hypoxylon new to the Czech Republic, and notes on other rare species. Czech Mycology 69(1): 77-108.

Zwijacz-Kozica T., 2003. Jodła w Tatrach. [Fir in the Tatra Mountains]. Las Polski 10: 23. 